\title{
Atividade Antimicrobiana do Óleo Essencial de Copaifera guianensis Frente à Alicyclobacillus acidoterrestris.
}

Angela Aparecida Silva (I), Idinea Fernandes Santos (I), Márcia Maria Anjos (I), Isabela Carolini Pascoli (I), Daniela Biral Prado (I), Celso Vataru Nakamura (I), Jane Martha Graton Mikcha (I), Miguel Machinski Júnior (I), Benício Alves Abreu Filho (I)

(I) UEM - Universidade Estadual de Maringá (Avenida Colombo, 5790 - Jardim Universitário, Maringá - PR, 87020-900)

\section{Resumo}

Os agentes antimicrobianos extraídos de vegetais possuem ação frente a uma vasta gama de micro-organismos, tanto nos Gram-negativos quanto nos Gram-positivos, além de possuírem ação em fungos e leveduras. Os óleos essenciais possuem boa aceitabilidade pelo consumidor, e são classificados pela FDA (Food and Drug Administration) como GRAS (Generally Recognized as Safe). Por este motivo, podem ser utilizados em produtos alimentícios. O suco de laranja concentrado é um produto de grande importância para o comércio de exportação do Brasil. Neste trabalho foi avaliada a ação do óleo essencial de Copaifera guianensis frente à Alicyclobacillus acidoterrestris (CBMAI 0244 ${ }^{\mathrm{T}}$ ) através da técnica da microdiluição seriada em placa de 96 poços. A. acidoterrestris é um bacilo acidofílico e termofílico, formador de esporos e não patogênico, no entanto, seu crescimento é favorecido em alimentos acidificados, mesmo que estes passem por processo de pasteurização. A presença de A. acidoterrestris no suco de laranja é um indicativo de que o produto está fora do padrão de qualidade, ou seja, existe a presença de micro-organismos. Através deste ensaio foi possível avaliar a Concentração Inibitória Mínima (CIM) e a Concentração Bactericida Mínima (CBM). O meio de cultura utilizado em nossos ensaios foi o BAT (Bacillus acidoterrestris), no qual

\footnotetext{
Referência:

Angela Aparecida Silva, Idinea Fernandes Santos, Márcia Maria Anjos, Isabela Carolini Pascoli, Daniela Biral Prado, Celso Vataru Nakamura, Jane Martha Graton Mikcha, Miguel Machinski Júnior, Benício Alves Abreu Filho. Atividade Antimicrobiana do Óleo Essencial de Copaifera guianensis Frente À Alicyclobacillus acidoterrestris.. In: Anais do 12을 Congresso Latinoamericano de Microbiologia e Higiene de Alimentos - MICROAL 2014 [= Blucher Food Science Proceedings, num.1, vol.1]. São Paulo: Editora Blucher, 2014. 
apresenta $\mathrm{pH}$ 4,0 ajustado com $\mathrm{HCl} / \mathrm{NaOH} 1 \mathrm{~mol} / \mathrm{L}$. As concentrações dos óleos essenciais avaliados variaram de 10.000 à $2.800 \mu \mathrm{g} / \mathrm{mL}$. O ensaio da CIM foi realizado a partir de microdiluições seriadas, com volume final de $100 \mu \mathrm{L}$ da solução (meio de cultura e óleo essencial) em cada poço da microplaca. Ao término das microdiluições foram adicionados $5 \mu \mathrm{L}$ do inóculo bacteriano na concentração de $10^{4} \mathrm{UFC} / \mathrm{mL}$ em cada poço da microplaca e incubado por um período de 24 horas a $45^{\circ} \mathrm{C}$. Foi considerada como a CIM a menor concentração capaz de inibir o crescimento de A. acidoterrestris no poço da microplaca. A CBM se procedeu através de microcultivos de $10 \mu \mathrm{L}$ realizados em placa ágar BAT dos poços que não houveram crescimento bacteriano observado visivelmente. Foi considerada CBM o não crescimento de colônias após plaqueamento seguido de incubação por 24 horas a $45^{\circ} \mathrm{C}$. A CIM e a CBM para C. guianensis foi 2.800 e $10.000 \mu \mathrm{g} / \mathrm{mL}$, respectivamente. Os resultados sugerem que o óleo essencial de $\mathrm{C}$. guianensis pode ser utilizado como agente antimicrobiano frente à A. acidoterrestris apesar da concentração elevada, além de haver necessidade de mais pesquisas quanto a sua ação combinada com mais de um método ou agente antibacteriano, a sua citotoxicidade e sua aplicação em sucos concentrados de laranja.

Palavras-Chave: Alicyclobacillus acidoterrestris, agente antibacteriano, Copaifera guianensis, suco de laranja

Agência de Fomento: PPG/UEM/CAPES. 